\title{
TISSUE PRESSURES IN PYOGENIC FLEXOR TENOSYNOVITIS OF THE FINGER
}

\section{COMPARTMENT SYNDROME AND ITS MANAGEMENT}

\author{
STEPHEN B. SCHNALL, TARYN VU-ROSE, PAUL D. HOLTOM, \\ BRIAN DOYLE, MILAN STEVANOVIC \\ From the University of Southern California, Los Angeles, USA
}

$\mathbf{W}$ Te investigated 14 patients with pyogenic flexor tenosynovitis for increased tissue pressures in involved digits. All showed raised pressures, in eight to $30 \mathrm{mmHg}$ or more. These levels are consistent with a compartment syndrome.

We describe the results of a modified operative technique which includes irrigation of the sheath and the leaving open of a lateral incision. This also allows early active mobilisation of the finger and has given satisfactory early results.

J Bone Joint Surg [Br] 1996;78-B:793-5.

Received 31 January 1995; Accepted after revision 6 February 1996

Purulent flexor tenosynovitis may result in considerable morbidity; irrigation and debridement are urgently required. The severe consequences of these infections may be due not only to the destruction of the tendon sheath and scarring, but also to inflammation which causes the finger to swell and become oedematous. We investigated tissue pressures in the fingers of patients with purulent flexor tenosynovitis to discover whether these were high enough to cause ischaemic damage. We also describe a surgical technique that combines compartment release of the finger with adequate drainage of the flexor sheath and allows for early movement.

\section{PATIENTS AND METHODS}

We investigated 14 patients with pyogenic flexor tenosynovitis by measuring compartment pressures in the digits which had the clinical signs as described by Kanavel (1943). These are pain on passive extension of a digit held in slight

S. B. Schnall, MD, Assistant Professor

T. Vu-Rose, MD, PGY IV Resident

B. Doyle, MD, Hand Fellow

M. Stevanovic, MD, PhD, Associate Professor

P. D. Holtom, MD, Assistant Professor of Clinical Medicine

Department of Orthopaedics, Los Angeles County and University of

Southern California Medical Center, 2025 Zonal Avenue, GNH 3900, Los

Angeles, California 90033, USA.

Correspondence should be sent to Dr S. B. Schnall at the University of Southern California, Orthopaedic Surgery Associates, 1510 San Pablo Street, Suite 322, Los Angeles, California 90033-4608, USA.

(C)1996 British Editorial Society of Bone and Joint Surgery 0301-620X/96/51225\$2.00 flexion, fusiform swelling, and tenderness along the sheath. We recorded the mechanism of any injury, the age of the patient and time from injury until treatment was begun.

Pressure measurement. The subcutaneous digital pressure in the affected finger was measured using either the Stryker (Santa Clara, California) or the Ace (Los Angeles, California) pressure monitors. At the time of admission a 21-gauge needle was introduced subcutaneously in the midline of the volar surface at the level of the proximal phalanx. In seven of the 14 patients, we measured pressure in the same digit on the opposite hand.

Operative technique. A midlateral skin incision is made from the distal to the proximal phalanx to decompress the finger; we did not routinely explore or release Cleland or Grayson's ligaments. The flexor sheath is opened distally, beyond the A4 pulley. A separate, transverse $2 \mathrm{~cm}$ palmar incision is made just proximal to the A1 pulley. The flexor sheath is irrigated using a paediatric feeding tube passed into the proximal sheath for about $2.5 \mathrm{~cm}$. The sheath is flushed with at least one litre of normal saline containing 50000 units of Bacitracin and irrigation continues until the drainage from the distal end of the sheath is clear. The tube is removed, the wounds are left open and a bulky hand dressing is applied. Active movements are started on the first postoperative day with the hand in a saline-betidine bath. The wounds are allowed to heal by secondary intention.

In a second group of 16 patients whose purulent flexor tenosynovitis had been treated by this method, the range of movement of the fingers was assessed in the postoperative period.

\section{RESULTS}

The age range of the patients was 18 to 50 years. The mean time from any initial injury until treatment started was 3.75 days (1 to 10). Twelve patients reported penetrating injuries, but two denied this, and no skin break could be identified. All 14 digits had raised pressures, the mean being $33 \mathrm{mmHg}$ (20 to 73; Table I). Eight patients had digital pressures of $30 \mathrm{mmHg}$ or more. The pressures in the seven normal fingers were all in the range of 0 to $5 \mathrm{mmHg}$. Many different organisms were cultured but Staphylococcus aureus and $\beta$-haemolytic streptococci of group A predominated. Antibiotic therapy, based on the culture results, was given intravenously and continued while the 
Table I. Details of 14 patients with compartment syndrome of the finger

\begin{tabular}{|c|c|c|c|c|c|c|c|}
\hline Case & $\begin{array}{l}\text { Age } \\
(\mathbf{y r})\end{array}$ & Cause & $\begin{array}{l}\text { Delay } \\
\text { in days }\end{array}$ & Digit & $\begin{array}{l}\text { Tissue } \\
\text { pressure } \\
(\mathbf{m m H g})\end{array}$ & Control & Culture and (comments) \\
\hline 1 & 41 & Glass, laceration & 3 & L thumb & 73 & 2 & $\beta$-streptococcus group $\mathrm{A}(\mathrm{HIV}+)$ \\
\hline 2 & 38 & Human bite & 10 & $\mathrm{~L}$ thumb & 32 & 0 & $\begin{array}{l}\text { Prevotella/Porphyromonas } \\
\text { Peptostreptococcus anaerobius }\end{array}$ \\
\hline 3 & 18 & Human bite & 3 & L ring & 48 & 0 & $\begin{array}{l}\text { Serratia marcescens, alpha streptococcus } \\
\text { (Second incision and drainage) }\end{array}$ \\
\hline 4 & 24 & Blister & 10 & L thumb & 26 & - & Staphylococcus aureus \\
\hline 5 & 46 & Glass & 1 & $\mathrm{R}$ long & 30 & 4 & $\begin{array}{l}\text { Proprionibacterium spp } \\
\text { Staphylococcus aureus, } \\
\text { Streptococcus epidermidis, streptococcus }\end{array}$ \\
\hline 6 & 32 & Knife, laceration & 3 & $\mathrm{~L}$ index & 28 & - & $\begin{array}{l}\beta \text {-streptococcus group A } \\
\text { Staphylococcus aureus }\end{array}$ \\
\hline 7 & 29 & Thorn & 3 & $\mathrm{R}$ long & 24 & - & $\beta$-streptococcus group A \\
\hline 8 & 31 & Splinter & 2 & $\mathrm{~L}$ index & 20 & 4 & $\begin{array}{l}\text { Staphylococcus epidermidis } \\
\text { (Wooden foreign body) }\end{array}$ \\
\hline 9 & 32 & Glass, laceration & 6 & $\mathrm{R}$ index & 20 & 4 & $\begin{array}{l}\text { Staphylococcus aureus, A-streptococcus gamma } \\
\text { Strep D. enterococcus }\end{array}$ \\
\hline 10 & 21 & Human bite & 3 & L small & 42 & - & No culture documented \\
\hline 11 & 50 & Unknown & 3 & $\mathrm{R}$ small & 32 & - & No growth \\
\hline 12 & 33 & Fall on hand & 1 & $\mathrm{~L}$ ring & 20 & - & No growth aerobe \\
\hline 13 & 26 & Car bumper laceration & 2 & $\mathrm{R}$ index & 40 & - & No growth \\
\hline 14 & 41 & Needle injection & 4 & $\mathrm{R}$ thumb & 34 & 5 & $\begin{array}{l}\text { Staphylococcus aureus (IV drug abuse) } \\
\text { Alpha streptococcus }\end{array}$ \\
\hline
\end{tabular}

patient remained in hospital, which was for an average of 7.5 days.

In the group of patients in whom we assessed the range of movement we used the criteria of Strickland and Glogovac (1980) for tendon repairs. An excellent result is return of over $85 \%$ of normal total active movement, good is $70 \%$ to $84 \%$, fair $50 \%$ to $69 \%$, and a poor result is less then $50 \%$ of normal movement. Normal active movement is defined as a total of $260^{\circ}$ at metacarpophalangeal, proximal interphalangeal, and distal interphalangeal joints (Table II). Within two weeks there were six excellent results, three good, five fair and two poor. Follow-up after two weeks was possible in only a few patients.

\section{DISCUSSION}

Ashton (1975) suggested that high tissue pressures may produce a sharp decline in blood flow, with complete cessation of flow if this pressure fell below the arteriolar pressure. Matsen (1975) has reviewed possible causes of compartment syndrome in relation to tissue pressure gradients. Mubaraek et al (1978) considered that a pressure greater than $30 \mathrm{mmHg}$ indicated the need for compartment release in patients with symptoms. Gaspard and Kohl (1975) showed that the skin itself may contribute to the development of a compartment syndrome, and Matsen (1975) stated that "although compartmental syndromes are usually discussed in relation to fascial compartments, increased pressure within any closed space may be sim-
Table II. Range of movement (degrees) in 16 other patients treated by the same method

\begin{tabular}{llllll}
\hline Case & MCP & PIP & Dip & Total & Grading \\
\hline 1 & 90 & 80 & 30 & 200 & Good \\
2 & 90 & 90 & 45 & 225 & Excellent \\
3 & 70 & 50 & 40 & 160 & Fair \\
4 & 75 & 45 & 30 & 150 & Fair \\
5 & 90 & 90 & 40 & 220 & Excellent \\
6 & 45 & 45 & 35 & 125 & Poor \\
7 & 90 & 90 & 45 & 225 & Excellent \\
8 & 90 & 90 & 80 & 260 & Excellent \\
9 & 90 & 90 & 20 & 200 & Good \\
10 & 60 & 30 & 30 & 120 & Poor \\
11 & 80 & 80 & 70 & 230 & Excellent \\
12 & 50 & 70 & 70 & 190 & Good \\
13 & 75 & 90 & 75 & 240 & Excellent \\
14 & 75 & 90 & 15 & 180 & Fair \\
15 & 75 & 45 & 50 & 170 & Fair \\
16 & 35 & 60 & 35 & 130 & Fair \\
\hline
\end{tabular}

ilarly detrimental". Infection may cause a compartment syndrome in the arm (Schnall, Holtom and Silva 1994).

We found raised subcutaneous tissue pressures in all affected fingers; eight digits showed pressures of $30 \mathrm{mmHg}$ or more. These levels are consistent with the diagnosis of compartment syndrome. We found no relation between tissue pressure and time from injury to treatment or the organism cultured.

Neviaser (1978) recommended closed sheath irrigation for the treatment of pyogenic flexor tenosynovitis and emphasised the importance of starting active exercises soon after the operation. Juliano and Eglseder (1991) described a 
limited open method of tendon sheath irrigation, with a skin incision which appeared to expose the entire tendon sheath. The latter was opened only in the area of injury, distal to the A4 pulley and proximal to the A1 pulley, and a catheter was inserted from distal to proximal and left in for 72 hours, when active exercises were begun.

The technique which we describe, used by the senior author for ten years, involves a midlateral skin incision without reference to the site of the primary injury, and does not expose the entire flexor sheath. We do not use an indwelling catheter after the initial irrigation in the operating theatre. This allows active exercises to begin on the first or second postoperative day. Juliano and Eglseder (1991) also used the criteria of Strickland and Glogovac (1980) to evaluate the results of surgery for pyogenic flexor tenosynovitis, reporting $88 \%$ to $100 \%$ excellent results, but direct comparisons with their series must take account of the severity of the infection. In their series, stage-I patients had a serous exudate, stage-II had cloudy purulent fluid, and stage-III patients had septic necrosis of tendons and sheath. Of the 28 cases which they report, ten were in stage I, 12 in stage II, and one in stage III. All 14 of our patients were in stages II or III. Juliano and Eglseder (1991) were able to follow their patients for an average of 9.5 months, while our patient population was transient and included many homeless persons. Long-term follow-up was impossible. Our results for range of movement are only preliminary and cannot easily be compared with those for other series.
Conclusions. Purulent flexor tenosynovitis may cause devastating damage to a digit. We have shown that the tissue pressures within the digit may be high enough to cause a compartment syndrome. The technique which we describe, leaving the wound open, addresses this problem, allows early movement and gives satisfactory early results.

No benefits in any form have been received or will be received from a commercial party related directly or indirectly to the subject of this article.

\section{REFERENCES}

Ashton H. The effect of increased tissue pressure on blood flow. Clin Orthop 1975;113:15-26.

Gaspard DJ, Kohl RD Jr. Compartmental syndromes in which the skin is the limiting boundary. Clin Orthop 1975;113:65-8.

Juliano PJ, Eglseder WA. Limited open-tendon-sheath irrigation in the treatment of pyogenic flexor tenosynovitis. Orthop Rev 1991;20:1065-9.

Kanavel AB. Infections of the hand. In: A guide to the surgical treatment of acute and chronic suppurative processes in the fingers, hand, and forearm. 7th ed. Philadelphia: Lea \& Febiger, 1943:241-2.

Matsen FA. Compartmental syndrome: an unified concept. Clin Orthop 1975;113:8-14.

Mubaraek SJ, Owen CA, Hargens AR, Garetto LP, Akeson WH. Acute compartment syndromes: diagnosis and treatment with the aid of the Wick catheter. J Bone Joint Surg [Am] 1978;60-A:1091-5.

Neviaser RJ. Closed tendon sheath irrigation for pyogenic flexor tenosynovitis. J Hand Surg Am 1978;3:462-6.

Schnall SB, Holtom PD, Silva E. Compartment syndrome associated with infection of the upper extremity. Clin Orthop 1994;306: 128-31.

Strickland JW, Glogovac SV. Digital function following flexor tendon repair in zone II: a comparison of immobilization and controlled passive motion techniques. J Hand Surg 1980;5:537-43. 